\title{
Renal and Ocular Complications and It's Relationship to Glycemic Control, CD95 and Soluble Fas (s Fas) in Type 1 Diabetes Mellitus (DM)
}

\author{
Hamdia Ezzat Ahmed*, Mahmoud Hashish*, \\ Zeinab Osheiba** Samia Taher*** and Karima youssef**** \\ *Clinical Pathology, ** Pediatric, *** Internal Medicine, \\ Faculty of Medicine, Al-Azhar University
}

\begin{abstract}
:
Type 1 diabetes mellitus (DM) is an autoimmune disease that results from the destruction of insulin-secreting pancreatic islet beta cells by autoreactive cells and their mediators.

The aim of this study was to analyze the expression of Fas receptors $\left(\mathrm{CD}_{95}\right)$ on $\mathrm{T}$ and $\mathrm{B}$ lymphocytes from patients with type $1 \mathrm{DM}$ and to assess the role of soluble Fas (s-Fas) in Fas mediated apoptosis of $\mathrm{T}$ and $\mathrm{B}$ lymphocytes, and to assess the role of glycemic control in renal and ocular complications.

This study was carried out on three groups:

Group I: consist of 16 patients with type 1 DM. Their age ranged from (11-18) years old with mean duration of illness $6 \pm 4$ months.

Group II: consist of 16 patients with long standing type 1 DM, their age ranged from $10-19$ years old, with mean duration of illness $30 \pm 10$ months.

Group III: consist of 16 healthy persons their age ranged from $10.5-19.5$ years old.

Results can be summarized as follows:

The incidence of positive microalbuminuria as well as incidence of retinopathy were significantly higher in group II (long standing DM) than newly diagnosed case (group I). Microalbuminuric patients had significantly higher $\mathrm{HbA}_{1} \mathrm{C}$ than others.

Newly diagnosed cases (group I) as well as (group II) long standing DM type 1 had significantly higher percentage of $\mathrm{T}$ and $\mathrm{B}$ lymphocyte bearing Fas receptors $\left(\mathrm{CD}_{95}\right)$ as compared to control group. Mean plasma level of s-Fas showed a significant increase in both DM groups as compared to control group.

There is no significant difference in the percentage of lymphocytes expressing $\mathrm{CD}_{95}$, and plasma s-Fas levels when compared microalbuminuric to normoalbuminuric patients. There was positive correlation between $\mathrm{HbA}_{1} \mathrm{C}$ and microalbuminuria in diabetic patients, there was positive correlation between $\mathrm{HBA}_{1} \mathrm{C}$ and \% of lymphocyte expressing the Fas receptors $\left(\mathrm{CD}_{95}\right)$. In both diabetic groups, positive correlation was found between $\mathrm{HbA}_{1} \mathrm{C}$ and s-Fas in DM type 1 . Also, positive correlation was found between $\%$ of cells expressing $\mathrm{CD}_{95}$ and s-Fas.

In conclusion, the study of the possible role of apoptosis of autoreactive lymphocytes and its regulation, in the pathogenesis of type $1 \mathrm{DM}$ may provide new therapeutic tools for the prevention of the disease. Further analysis, is necessary to finally settle this point, to elucidate the roles played by distinct immunological pathway in diabetes pathogenesis, this can lead to more effective and targeted therapies for the disease. Poor glycemic control is an essential initiating factor of defective apoptosis in type 1DM.
\end{abstract}

\section{Introduction}

Type 1 diabetes mellitus (DM) is one of the common chronic metabolic disorders, it is the results of complex interactions between multiple genetic variants and environmental factors (Paula et al., 2002).
As a result of increasing prevalence of type 1 diabetes in the last years, it becomes essential to search for the methods for prediction of the disease. Assessment of risk for type $1 \mathrm{DM}$ has become more 
sophisticated over last decade (Gillespie et al., 2002).

Type $1 \mathrm{DM}$ is an autoimmune disease that results from the destruction of insulin secreting pancreatic islet beta cells by autoreactive cells and their mediators (Almawi et al., 1999). It is well established that humoral and cellular immunity are dysregulated in type $1 \mathrm{DM}$ (Castanno and Eisenbarth, 1990). Yoon and Jun (1999) reported that the initial events that trigger the immune response leading to the selective destruction of the beta cells are poorly understood.

Apoptosis (programmed cell death), is an active genetically controlled process that removes damaged cells, physiological regulation of cell death is essential for the removal of potentially autoreactive lymphocytes during development and the removal of excess cells after the completion of an immune response (Krammer et al., 1994).

Thatte and Dahanukar (1997) reported that dysregulation of apoptosis may underlie the pathogenesis of autoim-mune disease by allowing abnormal autoreative lymphocyte to survive.

Fas (CD95/AP0-1) is an apoptosis surface receptor involved in controlling tissue function at multiple sites (Stassi et al., 1997). Engagement of Fas by Fas ligand (FasL) induces apoptosis of Fasbearing cells, which show a sequence of morphologic features including membrane blebbing, cellular shrinkage, and condensation of chromatin (Liles et al., 1996).

Soluble Fas proteins (s-Fas) are produced by alternative splicing of fas gene and by proteolytic cleavage of membrane Fas (m-Fas) receptor (Jiang, 1999). Elevated solulble form of Fas (s-Fas) which competes with the membrane associated molecule for the ligand binding and inhibits Fas- mediated apoptosis in patients with autoimmune diseases (Cheng et al., 1994).

The aim of the present work is to analyse the expression of fas receptors on $\mathrm{T}$ and $\mathrm{B}$ lymphocytes from patients with type 1 diabetes mellitus and to asses the role of soluble fas (s-fas) in fas mediated apoptosis of $\mathrm{T}$ and $\mathrm{B}$ lympohocytes and to assess the role of glycemic control in renal and ocular complications.

\section{Patients and Methods :}

The study was carried on 48 persons.

They were divided into three groups.

Group I : consist of 16 newly diagnosed cases of type 1DM in the first one year of the disease, mean duration of illness 6 month \pm 4 .

Group II: Consist of 16 long standing cases of type 1 DM (duration more than one years) mean duration of illness of 30 month \pm 10 .

Group III: 16 healthy subjects matched for age and sex served as control group.

All patients were on intensive insulin therapy receiving 3-4 daily subcutaneous injections. All patients and control were subjected to:

1) thorough history taking including age of onset, duration of the disease, schedule of insulin therapy, presence of diabetes complications (renal or ocular).

2) Complete clinical examination was also done and patients were subjected to fundus examination to screen diabetic retinopathy.

3) Laboratory work up :

\section{All the patients and control were subjected to the following laboratory analysis :}

a. fasting and post prandial blood sugar.

b. Glycosylated hemoglobin $\left(\mathrm{HbA}_{1} \mathrm{C}\right)$ : to assess the blood sugar control :The determination of glycosylated heamoglobin was done by microchrom-atographic methodology using Quick Columns "Kit" designed by Helena laboratories (USA). Hemolysed preparation of whole blood was mixed with a weakly binding cation exchange resin. The non-glycosylated hemoglobin bound to resin, leaving $\mathrm{HbA}_{1} \mathrm{C}$ free to be removed by means of resin separator (Bruns, 1984).

c. Lipid profile : Serum triglycerides cholesterol, high and low density lipoproteins (as routine annual follow up of patients).

d. Kidney and liver function tests (as routine annual follow up of patients) using Hitachi 911 clinical chemistry autoanalyzer 
e. Screening for microalbuminuria: (as routine annual follow up of patients).

Basically macroproteinuria was excluded by urinary strips (cumber 3, Bochringer Manhen Germany). Then Albumin creatinine ratio was determined in fresh morning sample using immunoturbidimetric assay at a maximum reaction velocity using Behring turbidimter system. Dade Behring Germany. Cut off level of microalbuminuria was considered as more than $30 \square \mathrm{g}$ albumin/mg creatinine.

Sampling was postponed if short term hyperglycemia, exercise, urinary tract infection, marked hypertension, heart failure, haematuria or acute febrile illness was present in the 24 hours preceding or during collection of urine, when 2 of 3 samples in 6 months interval were positive for microalbuminuria and urine strips was negative for albumin, the patients was considered to have microalbuminuria.

f. Immunofluorescence staining and flow cytometry analysis for Fas receptors (CD95) on B and T lymphocyte.

Peripheral blood mononuclear cells were isolated by density gradient centrifugation on Ficoll-hypaque. The cells were washed twice with phosphate buffered saline (PBS). For each case 3 tubes were prepared. Suitable volumes of the cells were put in each tube. In the first tube isotopic control was added. In the second, $10 \mu$ l of CD95-FITC and $10 \mu \mathrm{l} \mathrm{CD3-PE}$ were added to the cells.

In the third tube, $10 \mu \mathrm{l}$ CD95-FITC and 10 $\mu$ CD19-PE were added. The tubes were incubated for 10 minutes, washed twice with PBS and are ready for flow cytometry.

Acquisation and analysis were done on a BD FACS Calibur and a cellquest program, 10000 cells were acquired from each tube, the precent positive cells were recorded (Giordano et al., 1995).

g. Measuring soluble isoform of Fas (sFas) in the plasma by ELISA. The assay employed the quantitative sandwich enzyme immunoassay technique(Jodo et al., 1997).
Statistical analysis : The data were handled by the SPSS version 10, computer program. Student's t-test was used to assess the existence of significant difference between 2 means at the 0.05 level. Pearson's correlation coefficient was used to find the strength of correlation between quantitative variables $\mathrm{P}<0.05$ level significance (Wallach 2000).

\section{Results}

Table I demonstrates the clinical data and laboratory data in diabetics and control group as mean and standard deviation. It showed non significant difference regarding age, gender, dose of insulin per kilogram body weight per day, fasting blood sugar and glycosylated hemoglobin $\%$ when compared GI (Newly diagnosed DM type1) with GII (long standing DM-type1).

The incidence of positive microalbuminuria as well as incidence of retinopathy were significantly higher in the 2nd group (long standing DM) than newly diagnosed case (group I). Non of the patients under study had macroalbuminuria or overt nephropathy.

Figure 1 Shows significant difference between group I (newly diagnosed patients) and group II (long standing patients) regarding the prevalence of microalbuminuria $(\mathrm{P}=0.01)$

Table II Show comparison between microalbumiuric and normoalbuminuric patients.

Figure 2 Demonstrate forward scatter and side scatter of peripheral blood showing gating anlymphcytes.

Figure 3 Dot plot of $\mathrm{CD}_{95}$ FITC and CD3 PE showing the expression of $\mathrm{CD}_{95}$ (Fas) receptor on $\mathrm{T}$ cells .

Figure 4 Dot plot of $\mathrm{CD}_{95}$ FITC and CD19PE showing theexpression of $\mathrm{CD}_{95}$ (Fas) receptors on $\mathrm{B}$ cells.

Table III Show percentage of lymphocytes expressing the Fas receptors $\left(\mathrm{CD}_{95}\right)$ in different studied groups.

Newly diagnosed cases (group I)as well as group II long standing DM type I had significantly higher percentage of $\mathrm{T}$ 
and B lymphocyte bearing Fas receptors $\left(\mathrm{CD}_{95}\right)$ as compared to control group .

Table IV Demonstrate the percentage of lymphocytes expressing theFas receptors $\left(\mathrm{CD}_{95}\right)$ in microalbuminuric and normoalbuminuric patients.

No statistically difference was noted between the 2 groups.

Figure 5 and Table V Demonstrate that mean plasma Fas level (ng/ml) showed a significant increase in both DM groups as compared o control group.

Figure 6 Demonstrate the level of plasma (s-Fas) in microalbuminuric and normoalbuminuric DM patients
Mean plasma (s-Fas) showed non significant difference between both group.

There was direct correlation between $\mathrm{HbA}_{1} \mathrm{C}$ and Microalbuminuria in diabetic patient $(\mathrm{r}=0.750, \mathrm{p}=0.000)$.

There was direct correlation between $\mathrm{HbA}_{1} \mathrm{C}$ and $\%$ of lymphocyte expressing the Fas receptors $\left(\mathrm{CD}_{95}\right)$ in both diabetic groups $(\mathrm{r}=0.54, \mathrm{p}=0.004)$. There was direct correlation between $\mathrm{HbA}_{1} \mathrm{C}$ and (s-Fas) in $\mathrm{DM}(\mathrm{r}=0.573, \mathrm{p}=0.002)$.

There was direct correlation between $\%$ of cell expressing CD95 and (s-Fas) $(\mathrm{r}=0.520, \mathrm{p}=0.001)$.

Table I: Demographic and laboratory data of diabetic patient sand control group.

\begin{tabular}{|c|c|c|c|c|c|c|}
\hline Variable & $\begin{array}{l}\text { Group I } \\
\text { DM type I } \\
\text { N(16) }\end{array}$ & $\begin{array}{c}\text { Group II } \\
\text { DM type } 1 \\
\text { N(16) }\end{array}$ & $\begin{array}{c}\text { Group III } \\
\text { control group } \\
\mathbf{N}(16) \\
\end{array}$ & $\mathbf{G}_{\text {I }} \mathbf{V s G}_{\text {II }}$ & $\mathbf{G}_{\mathrm{I}} \mathbf{V s G}_{\mathrm{III}}$ & $\mathbf{G}_{\text {II }} \mathbf{V s G}_{\text {III }}$ \\
\hline \multirow{2}{*}{ Age/ years } & Mean \pm SD & Mean \pm SD & Mean \pm SD & $P$ value & $P$ value & $P$ value \\
\hline & $13 \pm 4$ & $16 \pm 3.5$ & $15.5 \pm 4.3$ & $\mathrm{NS}$ & $\mathrm{NS}$ & NS \\
\hline Gender & $\begin{array}{l}8 \text { females } \\
8 \text { males }\end{array}$ & $\begin{array}{l}9 \text { females } \\
7 \text { males }\end{array}$ & $\begin{array}{l}8 \text { females } \\
8 \text { males }\end{array}$ & $\begin{array}{l}\text { NS } \\
\text { NS }\end{array}$ & $\begin{array}{l}\text { NS } \\
\text { NS }\end{array}$ & $\begin{array}{l}\text { NS } \\
\text { NS }\end{array}$ \\
\hline $\begin{array}{l}\text { Duration of disease/ } \\
\text { months }\end{array}$ & $6 \pm 4$ & $30 \pm 10$ & 0 & $<0001 \mathrm{~s}$ & $<0.000 \mathrm{~s}$ & $<0.000 \mathrm{~s}$ \\
\hline $\begin{array}{l}\text { Insulin dose } \\
\text { u/kg/day }\end{array}$ & $1.2 \pm 0.5$ & $1.1 \pm 0.4$ & 0 & NS & $<0.000 \mathrm{~s}$ & $<0.000 \mathrm{~s}$ \\
\hline $\begin{array}{l}\text { Fasting blood } \\
\text { glucose } \mathrm{mg} / \mathrm{dl}\end{array}$ & $150 \pm 45$ & $165 \pm 40$ & $80 \pm 25$ & $\begin{array}{c}\mathrm{NS} \\
>0.05 \\
\end{array}$ & $<0.001$ & $<0.001$ \\
\hline $\mathrm{Hb} \mathrm{A}_{1} \mathrm{C} \%$ & $8.7 \pm 0.4$ & $9 \pm 0.6$ & $5.9 \pm .02$ & $\begin{array}{c}\mathrm{NS} \\
>0.05 \\
\end{array}$ & $<0.001$ & $<0.001$ \\
\hline $\begin{array}{l}\text { Incidence of micro } \\
\text { albuminuria \% }\end{array}$ & 6.25 & $12.5 \%$ & 0 & $<0.01$ & $<0.000$ & $<0.000$ \\
\hline $\begin{array}{c}\text { Incidence of } \\
\text { retinopathy \% }\end{array}$ & 0 & 6.25 & 0 & $<0.000 \mathrm{~S}$ & NS & $\begin{array}{l}<0.000 \\
\text { signif. }\end{array}$ \\
\hline
\end{tabular}

Table II: Show comparison between microalbuminuric \& normoalbuminuric patients.

\begin{tabular}{|c|c|c|c|}
\hline & $\begin{array}{c}\text { Microalbuminuric } \\
\text { Patients (n=3) mean } \\
\mathbf{\pm S D}\end{array}$ & $\begin{array}{c}\text { Normoalbuminuric } \\
\text { Patients }(\mathbf{n = 2 9}) \\
\text { mean } \pm \text { SD }\end{array}$ & P value \\
\hline $\begin{array}{c}\text { Age / years } \\
\begin{array}{c}\text { Duration of disease } \\
\text { / months }\end{array}\end{array}$ & $15.8 \pm 3.9$ & $14.9 \pm 4.2$ & $\mathrm{NS}$ \\
\hline $\begin{array}{c}\text { Insulin dose } \mathbf{m} \\
\square / \mathbf{k g} / \mathbf{d a y}\end{array}$ & $1.2 \pm 0.5$ & $20 \pm 3$ & $\mathrm{NS}$ \\
\hline $\mathbf{H b A}_{\mathbf{1}} \mathbf{C \%}$ & $9.5 \pm 0.6$ & $1.1 \pm 0.4$ & $\mathrm{NS}$ \\
\hline
\end{tabular}


Table III: Percentage of $T$ and $B$ lyamphocytes expressing the Fas receptors $\left(C D_{95}\right)$ in different studied groups

\begin{tabular}{||c|c|c|c|c|c|c||}
\hline Variables & $\begin{array}{c}\text { Group I } \\
\text { DM type I } \\
\mathbf{N}=(\mathbf{1 6})\end{array}$ & $\begin{array}{c}\text { Group II } \\
\mathbf{D M} \text { type I } \\
\mathbf{N}=(\mathbf{1 6})\end{array}$ & $\begin{array}{c}\text { Group III } \\
\text { Control } \\
\text { group } \\
\mathbf{N}=(\mathbf{1 6})\end{array}$ & $\mathbf{G}_{\mathbf{I}} \mathbf{V s G}_{\mathbf{I I}}$ & $\mathbf{G}_{\mathbf{I}} \mathbf{V s G}_{\text {III }}$ & $\mathbf{G}_{\mathbf{I I}} \mathbf{V s G}_{\mathrm{III}}$ \\
\hline T cells \% & $37 \pm 8.4$ & $35.5 \pm 9$ & $2.6 \pm 0.56$ & $>0.05 \mathrm{NS}$ & $<.0001$ & $<0.0001$ \\
\hline B cells \% & $2.4 \pm 0.4$ & $2.2 \pm 0.5$ & $1.6 \pm 0.9$ & $>0.05 \mathrm{NS}$ & $<0.05$ & $<0.05$ \\
\hline
\end{tabular}

Table IV: Percentage of $T$ and $B$ lymphocyte expressing the Fas receptor $\left(C_{95}\right)$ in microalbuminuric \& normoalbuminuric patients.

\begin{tabular}{|c|c|c|c|}
\hline Variable & Microalbuminuric & Normoalbuminuric & P value \\
\hline T cells \% & $36.2 \pm 8.8$ & $36.9 \pm 9.4$ & $>0.05 \mathrm{NS}$ \\
\hline B cells \% & $2.3 \pm 0.5$ & $2.4 \pm 0.6$ & $>0.05 \mathrm{NS}$ \\
\hline
\end{tabular}

Table V: Plasma (s-Fas) in different studied group

\begin{tabular}{|c|c|c|c|c|c|c|}
\hline Variables & $\begin{array}{c}\text { Group I } \\
\text { DM type I } \\
\mathrm{N}=(16) \\
\text { Mean } \pm \text { SD }\end{array}$ & $\begin{array}{c}\text { Group II } \\
\text { DM type I } \\
\text { N=(16) } \\
\text { Mean } \pm \text { SD }\end{array}$ & $\begin{array}{c}\text { Group III } \\
\text { Control group } \\
\mathrm{N}=(\mathbf{1 6}) \\
\text { Mean } \pm \text { SD } \\
\end{array}$ & $\begin{array}{l}\mathbf{G}_{\mathrm{I}} \mathrm{VsG}_{\text {II }} \\
\text { P value }\end{array}$ & $\begin{array}{c}\mathbf{G}_{1} \mathrm{VsG}_{\text {III }} \\
\text { P value }\end{array}$ & $\begin{array}{c}\mathbf{G}_{\mathrm{II}} \mathrm{VsG}_{\mathrm{III}} \\
\text { P value }\end{array}$ \\
\hline $\begin{array}{l}\text { S-Fas } \\
\text { ng/ml }\end{array}$ & $7.2 \pm 1.9$ & $6.9 \pm 2$ & $4 \pm 1.2$ & $\begin{array}{c}\geq 0.05 \\
\mathrm{NS}\end{array}$ & $<.001 \mathrm{~S}$ & $<0.001 \mathrm{~S}$ \\
\hline
\end{tabular}

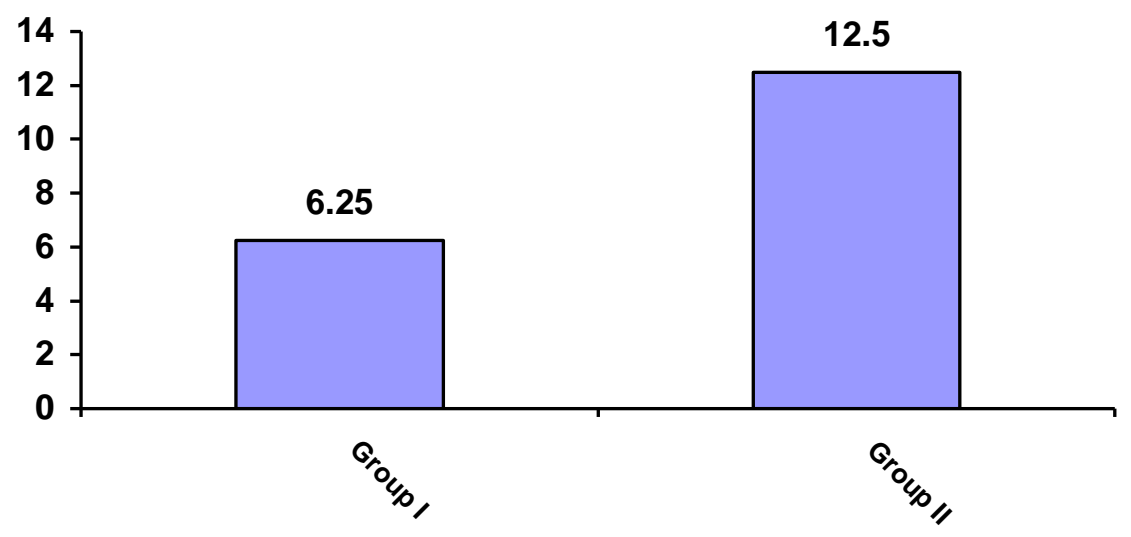

Fig. (1): Prevalence of microalbuminuria in diabetic groups. 


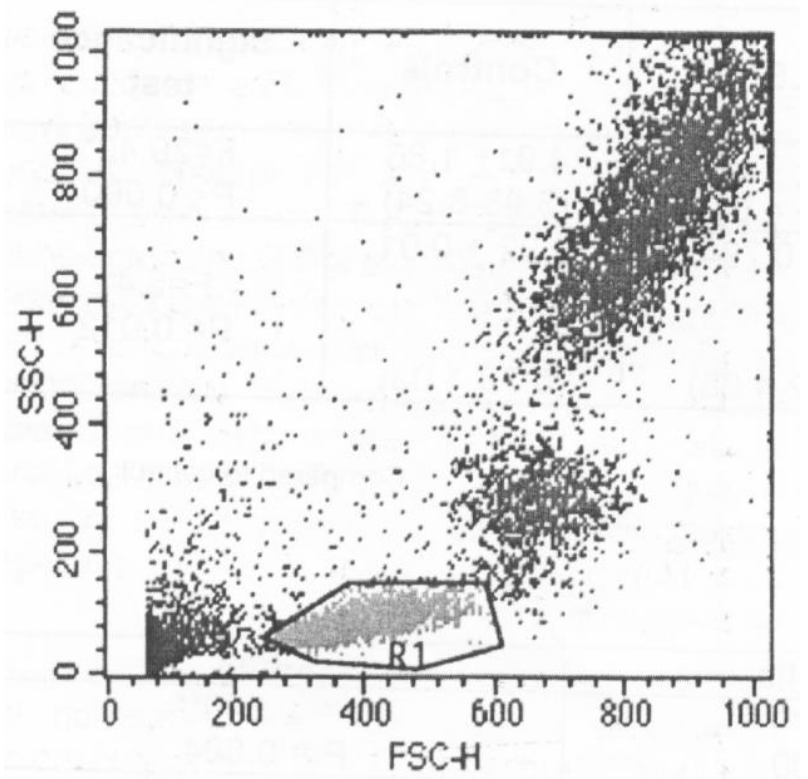

Fig. (2): Forward scatter and side scatter of peripheral blood showing gating on lymphocytes.

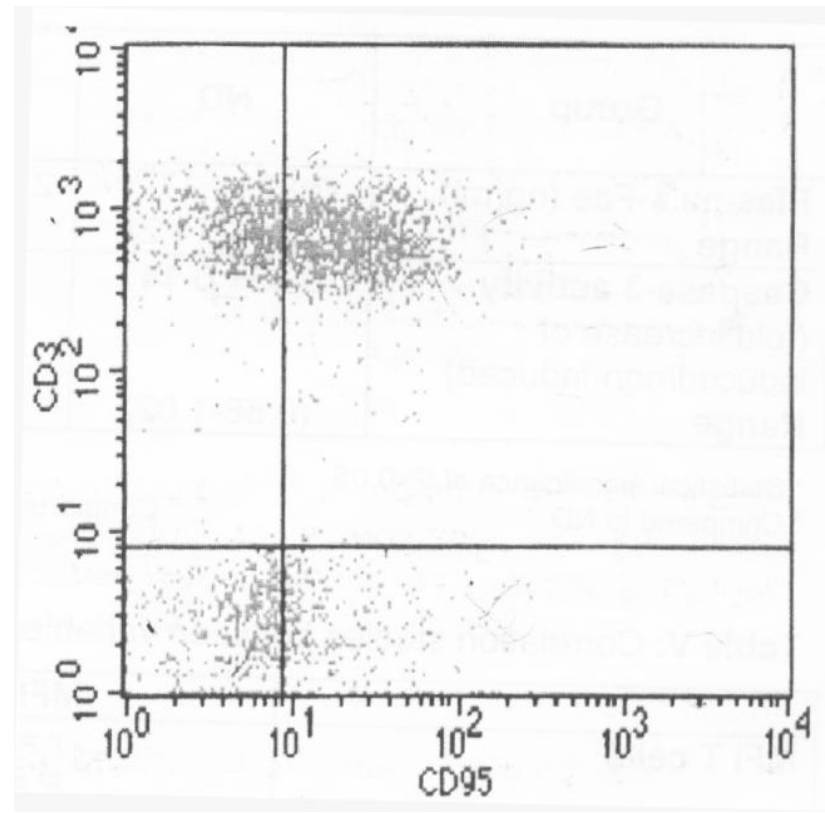

Fig. (3): Dot plot of CD95 FITC and CD3 PE showing the expression of CD95 (Fas) receptors on $T$ cells. 


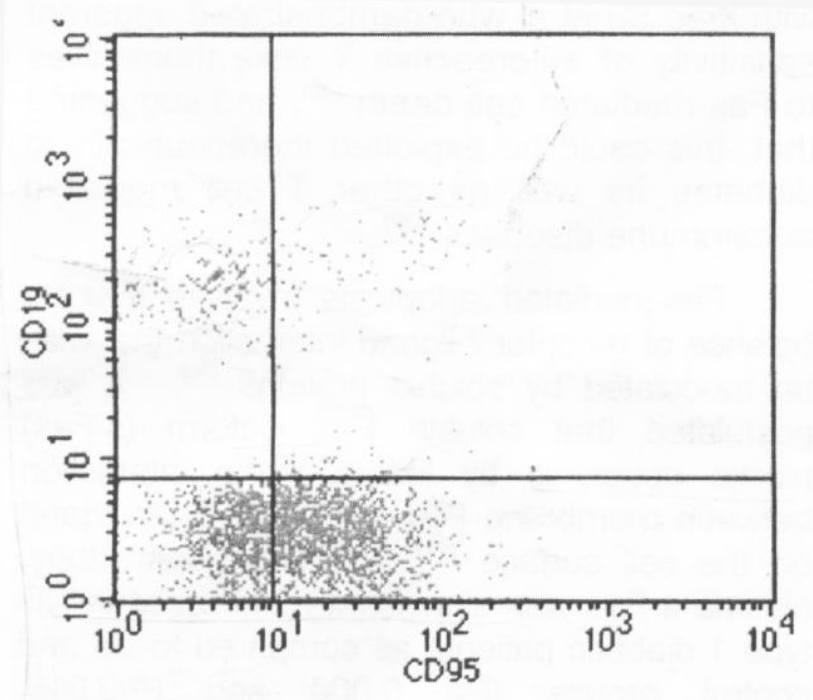

Fig. (4): Dot plot of CD95 FITC and CD 19 PE showing the expression of CD95 (Fas) receptors on B-cells.

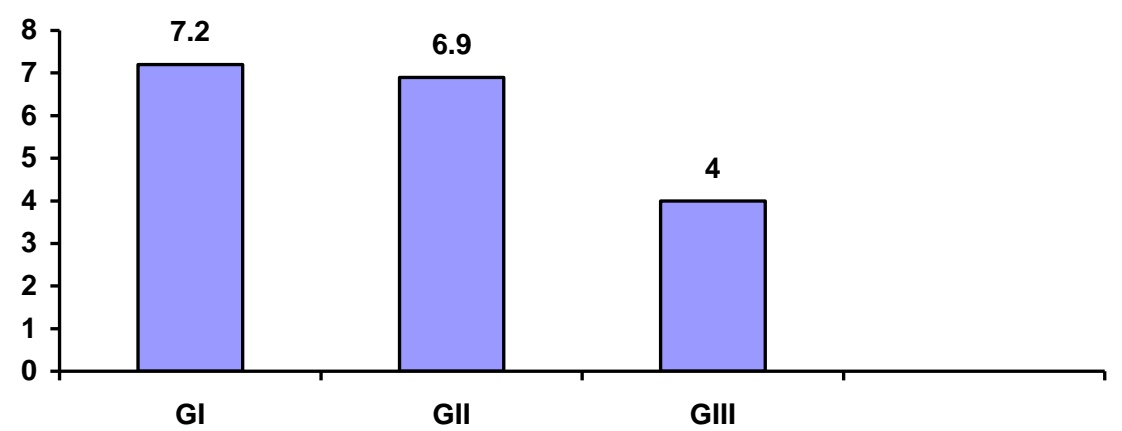

Fig. (5): Mean plasma (s-Fas) in different studied groups.

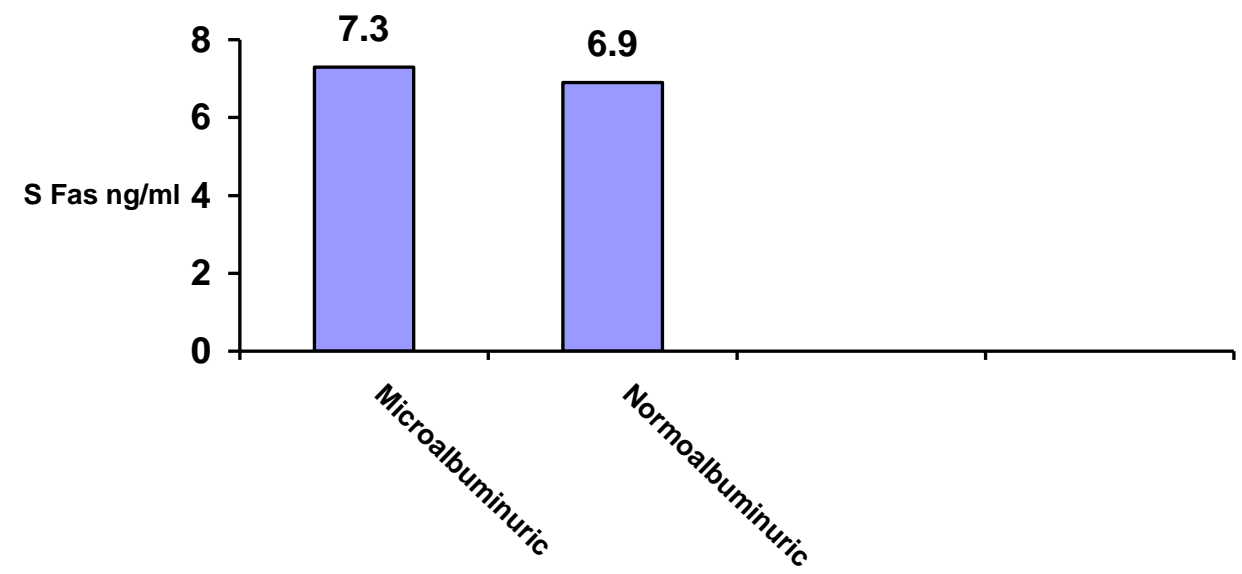

Figure 6: Demonstrate the level of plasma (s-Fas) in microalbuminuric and normoalbuminuric DM patients. 


\section{Discussion}

Type 1 insulin dependant diabetes mellitus IDDM is regarded as an immune mediated disease in which the beta cells of the pancreatic islets of langerhans are destroyed as a consequence of inflammatory reactions triggered by activation of $\mathrm{T}$ cells specific for Beta cell associated Ag (Gregg et al.,2005).

The autoreactive $\mathrm{T}$ lymphocytes may persist in peripheral blood of patients with high risk DM type 1 . Defective elimination of autoreactive $\mathrm{T}$ cells may result in autodestructive damage of islets beta cells (Tchorzewski et al., 2001).

In the immune system programmed cell death has been show to play a critical role in both $\mathrm{T}$ and $\mathrm{B}$ cell development as well as in the homeostatic regulation of mature peripheral lymphoid populations (Cohen et al., 1992). In particular, apoptotic signaling through the tumour necrosis factor (TNF) family receptor Fas (CD95) and its ligand (CD95L) is central to the regulation of mature lymphocyte growth and differentiation (Nagata and Golstein, 1995). Bettinardi et al. (1997) reported that missence mutations in the Fas gene resulting in autoimmune lymphoproliferative syndrome. So apoptosis mediated by Fas is important in maintaining peripheral self-tolerance and in down regulating the immune response and could have a role in immune-mediated beta cell destruction.

In this study there was no significant difference between newly diagnosed and long standing DM type 1 as regard, Ag, Gender, dose of insulin, fasting blood glucose level, and $\mathrm{HbA}_{1} \mathrm{C}$.

Microalbuminuria was present in 6.25 $\%$ of newely diagnosed type- 1 DM patients, while it was found in $12.5 \%$ of long standing type-1 DM patients. Similar results was found previously by Fagerudd et al. (1999). It has been hypothesized that poor glycemic control is not an essential initiating factor of microalbuminuria but once there is predisposition to develop nephropathy, worsening of the metabolic control accelerates the rise in albumin excretion. This study revealed a significant higher $\mathrm{HbA} 1 \mathrm{C}$ values in microalbuminuric group. Also there was significant positive correlation of microalbuminuria with HbA1C. Similar results have been reported before by Holl et al. (1999).

The results of this study revealed that the presence of retinopathy was significantly higher in long standing DM type 1 than in newly diagnosed cases. Rema et al. (2002) reported that retinopathy was related to duration of the disease it had significantly higher incidence in cases with duration more than 5years and it is related to poor glycenic control.

Our work demonstrated a significantly higher percentage of $\mathrm{T}$ cells expressing Fas receptors (CD95) in newly diagnosed and long standing DM type 1 cases than control groups.

Previous studies showed that the elimination of clones which have undergone the initial expansion phase in due to an apoptotic process called activation induced cell death(AICD) which correlates with CD95 (Fas) expression on activated lymphocytes (Arnold et al., 1992 \& Green and Scot 1994).

Fowlkes and Ramsdell (1993) reported that defective apoptosis of peripheral lymphocytes was found in DM type 1 patients and this may affect the capacity to maintain the normal levels of peripheral tolerance essential for protection from autoimmune disease and may contribute to pathogenesis of type $1 \mathrm{DM}$.

Our results in agreement with Dharnidharka et al. (2002), who demonstrated defects in $\mathrm{T}$ cell activation and peripheral apoptosis in non-obese diabetic mouse, model of type 1 diabetes mellitus, and found that administration of the Fas agonist immediately after onset of diabetes led to reversal of diabetes in non obese diabetic mouse and suggested that inducing peripheral $\mathrm{T}$ cell apoptosis may be a potential method for reversal of autoimmune disease. Mean while DeFranco et al. (2001) found defective function of Fas receptors on $\mathrm{T}$ cells, which were expressed at normal levels, in only a minority of type 
1 diabetus mellitus patients, and it was more pronounced in polyreactive type-1 (type 1 DM with other autoimmune diseases).

In contrast, Giardano et al. (1995) reported low bcl2 (anti-apoptotic protein) expression and increased spontaneous apoptosis in T-lymphocytes from newly diagnosed IDDM patients.

Nolsoe et al. (2000) reported that there is no over all evidence for linkage of Fas polymorphism to type $1 \mathrm{DM}$ and so the Fas gene does not contribute to genetic susceptibility for type 1DM.

In the present study plasma (s-Fas) was significantly increased in newely diagnosed and long standing cases of type 1 DM as compared to control group. This results in agreement with results obtained by Al-Maini et al. (2000).

In contrast Goel et al. (1995), showed significant decrease of plasma s-Fas in patient with autoimmune disease. Fasmediated apoptosis involved delicate balance of receptor / ligand interaction that my be modulated by soluble proteins (Waring and Mullbacher 1999).

Mouawad et al. (1997) reported that soluble Fas isoform (s-Fas) block apoptosis by inhibiting the interaction between membrane Fas receptor and its ligand on the cell surface.

Our work demonstrate that there was direct correlation between $\mathrm{HbA1C}$ and \% of lymphocyte expressing the Fas receptors in both diabetic groups, also there was direct correlation between $\mathrm{HbA1C}$ and (s-Fas) in newly diagnosed and long standing cases of type 1 DM. Poor glycemic control is an essential initiating factor of defective apoptosis in type 1DM.

\section{In Conclusion:}

The study of the possible role of apoptosis of autoreactive lymphocytes and its regulation, in the pathogenesis of type 1 DM may provide new therapeutic tools for the prevention of the disease. Further analysis, is necessary to finally settle this point, to elucidate the roles played by distinct immunological pathway in diabetes pathogenesis, this can lead to more effective and targeted therapies for the disease. Poor glycemic control is an essential initiating factor of defective apoptosis in type 1DM.

\section{References}

1) Al Maini M, Mountz J and Al-Mohri H (2000): Serum levels of soluble Fas correlate with indices of organ damage in systemic lypus erythematosus. Lupus 9:132-9.

2) Almawi WI, Tamim H, Azar ST (1999): T helper type 1 and 2 cytokines mediate the onset and progression of type 1 (insulindependent) diabetes. J Clin Endocrinol Metab 84(5):1497-502.

3) Arnold B, Schonrich G and Hammerling GI (1992): Extrathymic $T$ cell selection. Curr OP Immunol 4:166-70.

4) Bettinardi A, Brugnoni $D$ and Quiros $R$ (1997): Missence mutations in the Fas gene resulting in autoimmune lymphoproliferative syndrome : a molecular and immunological analysis. Blood 89:902-9.

5) Bruns DE (1984): Detection of glycosylated heamoglobin using affinity column method (Helena Glyco Tek). Clin. Chem 30(4), 569-571.

6) Castanno L and Eisenbarth F (1990): Type 1 diabetes, a chronic autoimmune disease of human, mouse and rat, Ann Rev Immunol 8:647-79.

7) Cheng J, Zhou T and Liu C (1994): Protection from Fas- mediated apoptosis by a soluble form of the fas molecule. Science 263: 1759-62.

8) Cohen JJ, Duke RC and Fadok VA (1992): Apoptosis and programmed cell death in Immunity. Annu Rev Immunol; 10:267-93.

9) DeFranco S, Bonissoni S and Cerutti F (2001): Defective function of Fas in patients with type 1 diabetes mellitus associated with other autoimmune diseases. Diabetes 50(3)483-8.

10) Dharnidharka VR, VanPatten $Y$ and Bahjat FR (2002): Fas stimulation results in selective islet infiltrate apoptosis in situ and reversal of diabetes. Ann Ny. Acad Sci 958:160-2.

11) Fagerudd KJ, PlterssonC and Grnhagen R (1999): Impact of a family history of type 11 (non-insulin -dependent) DM on the risk of diabetic nephropathy in patients 
with type 1 DM. Diabetologia, 42 (5):519526.

12) Fowlkes BJ and Ramsdell F (1993): $T$ cell tolerance. Curr Opin Immunal 5:873-9

13) Gillespie KM, Gale EA and Bingley PJ (2002): High familial risk and genetic susceptibility in early onset childhood diabetes. Diabetes. 51(1): 210-4.

14) Giordano C, DeMaria $\mathbf{R}$ and Stassi $\mathbf{G}$ (1995): Defective expression of the apoptosis-inducing CD95 (Fas/Apo-1) molecule on $\mathrm{T}$ and $\mathrm{B}$ cells in IDDM. Diabetologia 38:1449-54.

15) Girdano $C$, Stassi $G$ and Todaro $M$ (1995): Low bcL-2expression and increased spontaneous apoptosis in $\mathrm{T}$ lymphocytes from Newly diagnosed IDDM patients. Diabetogia 38 (8):953-8.

16) Goel N, Ulrich DT and St Clair EW (1995): Lack of correlation between serum soluble fas / Apo-1 levels and autoimmune diseases. Arthritis Rheum 38(12):173-43.

17) Green DR and Scott DW (1994): Activation - induced apoptosis in lymphocytes. Curr OP Immunol 6:476-87.

18) Gregg RK, Bell JJ, Lee HH and Join R (2005): IL10 diminishes CTLA-4 expression on islet resident $\mathrm{T}$ cells and sustains their activation rather than tolerance. J Immunol 15:174(2) 662-70.

19) Holl RW, Grabert M, Thon A and Heinz E (1999): Urinary excretion of albumin in adolescents with type 1 diabetes : persistent versus intermittent microalbuminuria and relationship to duration of diabetes, sex and metabolic control : Diabetes Care, 22(9):1555-60.

20) Jiang Zhu (1999): Alternative splicing and programmed cell death. Proc Soc Exp Biol Med 220:64-72.

21) Jodo S, Kobayashi $\mathbf{S}$ and Kayagaki $\mathbf{N}$ (1995): Serum levels of soluble Fas / Apo-1 (CD95) and its molecular structure in patient with systemic lypus erythematosus (SLE) and other autoimmune diseases. Clin Exp Immunol, 107(1):89-95.

22) Krammer PH, Behrmann $I$ and Danel $P$ (1994): Regulation of apoptosis in the immune system. Curr OP Immunol 6:263-7.

23) Liles WC, Kiener PA and Ledbetter JA (1996): Differential expression of Fas (CD95) and Fas ligand on normal human phagocytes implications for the regulation of apoptosis in neutrophils. J Exp Med, 184:429-40.

24) Mouawad R, Khayat D, Soubrane C (1997): Plasma Fas ligand, an inducer of apoptosis, and plasma soluble Fas, an inhibitor of apoptosis, in advanced melanoma. Arthritis Rheum. 40(6):1126-9.

25) Nagata $S$ and Golstein $P$ (1995): The Fas death factor. Science, 267:1449-56.

26) Nolsoe R, Kristiansen $O P$ and Saugthongpitag K (2000): Complete molecular scanning of the human fas gene : mutational analysis and linkage studies in families with type 1 diabetes mellitus. The Danish study group of diabetes and childhood and the Danish IDDM. Epidemiology and Genetics Group : Diabetologia43(6):8008.

27) Paula W, Maren $T$ and Schevner $T$ (2002): Can family history be used as a tool for public health on preventive medicine? Genetics in Medicine 4(4):304-310.

28) Rema M, Saravanan $G$ and Deepa $R$ (2002): familial clustering of diabetic retinopathy in south Indian type 2 diabetic patients. Diabet. Med Nov, 19(11):910-6.

29) Stassi G, DeMaria $R$ and Trucco $G$ (1997): Nitric oxide primes pancreatic beta cells for Fas mediated destruction in insulin dependent diabetes mellitus. J Exp Med, 186 (8):1193-2000.

30) Tchorzewski H, Glowacka E, Banasik M, Lewkowicy $P$ and Szalapska $M$ (2001): Activated $\mathrm{T}$ lymphocytes from patients with high risks of type 1 diabetes mellitus have different ability to produce interferon - gamma, Interleukin-6 and interleukin-10 and undergo anti CD95 induced apoptosis after insulin stimulation. Immunol Lett 15; 75(3):225-34.

31) Wallach J (2000): Interpretation of diagnostic tests. $7^{\text {th }}$ ed. Williams and Wilkins. Phildelphia USA.

32) Waring P and Mullbacher A (1999): Cell death induced by the Fas/Fas ligand pathway and its role in pathology. Immunol cell Biol. 77(4):312-7.

33) Yoon JW and Jun HS (1999): Cellular and molecular roles of beta cell autoantigens, macrophages and $\mathrm{T}$ cells in the pathogenesis of autoimmune diabetes. Arc pharm Res 22(5):437-47. 


\section{مضاعفات الكلي والعيون وعلاقتها بمستوى السكر وسي دي 95 والفاس الأ|ئب في

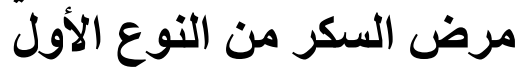

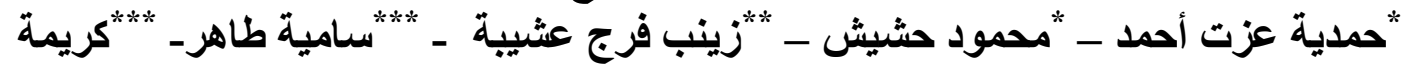 يوسف \\ "أقسام الباتولوجيا الاكلينيكية ـ "الأطفال ـ ـ**" الباطنة العامة ـ كلية الطب جامعة الازهر}

مرض السكر من النوع الأول يعتبر من أمر اض المناعة الذاتيـة وينتج من تكسير

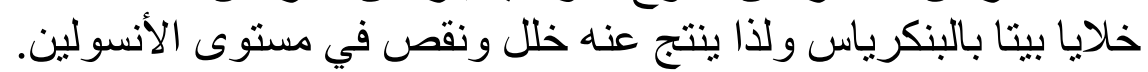

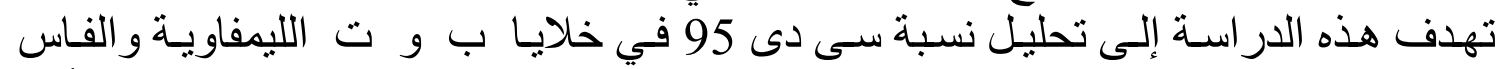
الذائب و علاقتهم بالمضاعفات التي تحدث بالكلى و العيون في مرض في السكر من النوع الأول

وقد تم اختيار ثلاث مجمو عات للانضمام لهذه الدر اسة:

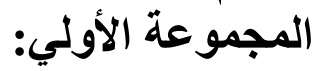

وتكونت من 16 مريض بمرض الاولم السكر من النوع الأول ومتوسط اعمـار هم يتر اوح بين 11

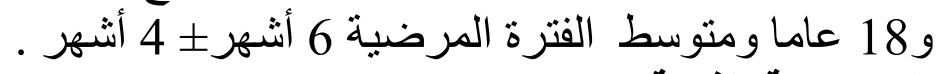
المجموعة الثانية :

تكونت من 16 مريض يعانون : 10 من من مرض السكر من النوع الأول ومنوسط أعمار هم يتر اوح

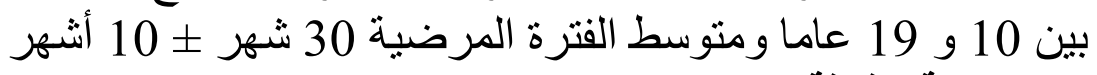
المجموعة الثالثة :

تكونت من 16 شخصا طبيعيا لا يعانون من أى أمر اض وتعتبر المجمو عة الضابطة.

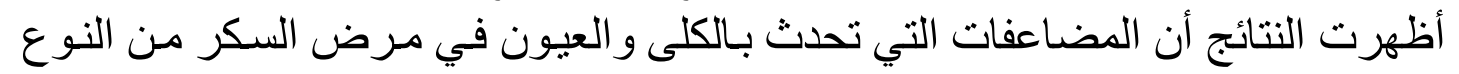

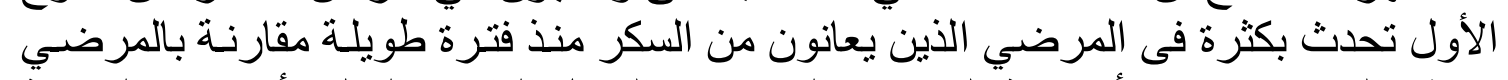

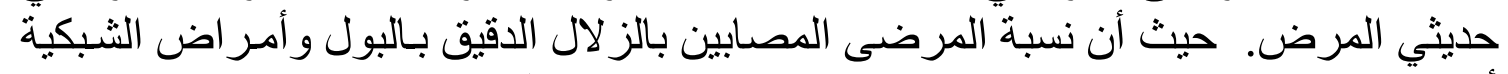

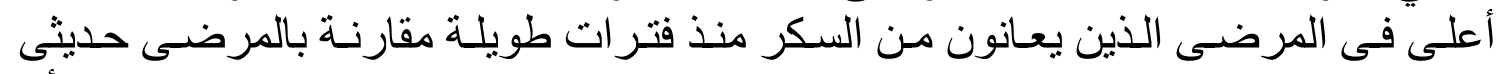

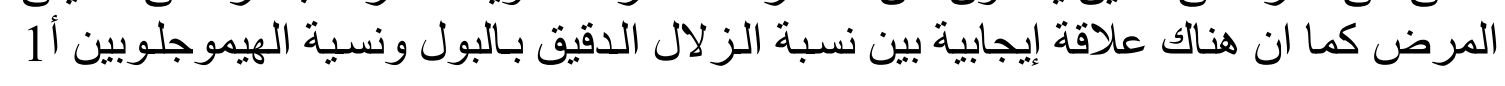

المرضى حديثي الإصابة بالسكر وكذلك المرضى الذين يعانون منه منذ فتر ات طويلة لديهر

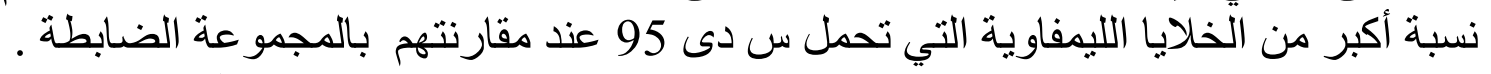

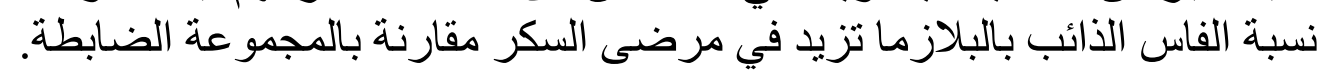

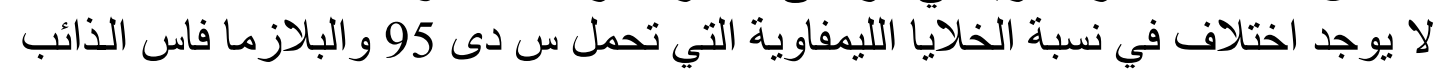

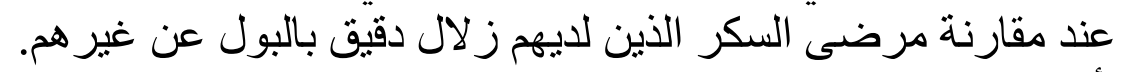

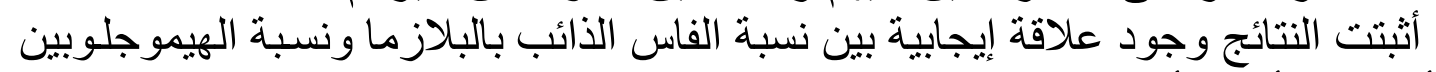

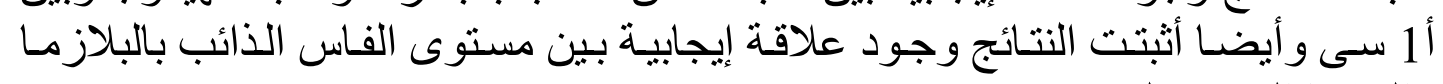
و الخلايا التي تحمل سى دى 95. 